„Bohemistyka” 2019, nr 1, ISSN 1642-9893

Olga V. RAINA

DOI: $10.14746 /$ bo.2019.1.2

Alena S. SHESTAKOVA-STUKUN

St. Petersburg State University

\section{Ethnic stereotypes in Polish and Czech proverbs}

Keywords: paremiology, proverbs, Polish, Czech, stereotypes

\section{Abstract}

Proverb is a genre of folklore and it is thought reflection of the whole nation. The proverbs contain rich material about the perception of the world and reflect the specific conditions of development of material and spiritual culture. The examined proverbs illustrate the stereotypes of the Poles and Czechs about themselves, their neighbours and other nations.

Proverbs as a folklore genre contain a fragment of the language picture of the world, give an idea of the standards existing in other cultures, as well as representatives of other ethnic groups. The simplified image that arises from the linguistic and cultural interaction of nations with each other is called an ethnic stereotype. The purpose of the study was to determine the characteristics of various ethnic stereotypes in Polish and Czech proverbs. The autostereotype of the Pole, the Czech, and also the heterostereotypes of various ethnic groups: the Jews, the Germans, the Gypsies, the Turks, and the Hungarians were described.

\section{The autostereotype of the Pole}

The delineation of the autostereotype is usually positive. In the first place in the Polish autostereotype one can designate love for the motherland.

Dobra Francja, chwalebna Hiszpania, bogate Niemcy, ale najlepsza Polska (NKPP II, p. 1003)

Dla Polaków ojciec Kraków, a Warszawa matka (NKPP II, p. 1003)
The aspiration for protection their country from enemies, wars is the logical desire of every patriot, as the Poles appear in their proverbs.

Nigdy w Polsce nie zabraknie żelaza do broni, rycerstwa do koni, żyta, lnu, pszenicy i pełnej wina piwnicy (NKPP II, p. 1005).

Polska była niebem dla szlachty, czyśćcem dla mieszczan, piekłem dla chłopów, a rajem dla Żydów (NKPP II, p. 1007)

Poland is a rich region where there is food for the body and the spirit. Nevertheless, at the same time with the love for their country, there is indifference to ruling over it and not only:

Nierządem Polska stoi (NKPP II, p. 1005).

Chcesz zamek mieć pusty, porucz go Polakom (NKPP II, p. 1002).

Patriotism contrasts with criticism of the authorities in the proverbs.

A Pole is a brave, courageous, noble, hardworking, able to stand up for himself.

Co Polak, to rycerz (NKPP II, p. 1002)

Polacy nie gęsi i swój język mają (NKPP II, p. 1006)

Nie chodź na Lachów bez armat (NKPP II, p. 293).

Od Polaka albo Rusi państwo Turków upaść musi (NKPP II, p. 1006).

Endurance and unpretentiousness can be described as the qualities which are inherent in the Polish people.

Mróz się poprawił, Polak wạsa zakręcił (NKPP II, p. 1004).

Czorno, gorsko, ale polsko (NKPP II, p. 1003).

Francuz skacze, Niemiec płacze, Polak stoi, wąsy stroi, żadnego kpa się nie boi (NKPP II, p. 1003)

Religion takes a special place in the Polish paremiological fund. Polak to katolik (NKPP II, p. 1006).

Lichy Polak, co nie pości (NKPP II, p. 1004).

Lepsza łaska boska niżli cała Polska (NKPP II, p. 1004).

Na polskie - to Pan Bóg się rodzi, a na ruskie - to krzci (NKPP II, p. 1005).

Polacy zawsze wiarę dzierżą (NKPP II, p. 1006).

For a long period from the $\mathrm{X}$ century, Catholicism firmly entered the life of every representative of the Polish nation and was reflected in folk art. 
At the same time, in addition to the noble and positive traits of character, the mentality contains the opinion of the Poles about themselves as poor, careless, and sometimes even loutish people.

Polak jako małpa: co ujrzy, to by chciał mieć (NKPP II, p. 1006).

U Polaka: co w sercu, to i na języku (NKPP II, p. 1009).

Lach a chart, to jeden czart; chłop a Świnia, to jedno imia (NKPP II, p. 293).

Jak i Polak, tak i Czech, by nie robił, to be zdechł (NKPP II, p. 1004).

One of the important features of the Polish mentality, expressed in proverbs, is the love for food.

Polak gdy głodny, to zły (NKPP II, p. 1006).

Polak mówi: zjadłbym co z kim (NKPP II, p. 1006).

Polak zuch, kiedy ma pełny brzuch (NKPP II, p. 1007).

Włoch się sałatą karmi, Polak na niej schudnie (NKPP II, p. 1010)

Addiction to alcohol can also be noted in the proverbs.

Moda polska - podpić i pobić (NKPP II, p. 1004).

W Polaku męstwo, siła, by tylko trzeźwość była (NKPP II, p. 1010).

W Polszcze jeść, w Węgrzech pić, w Niemczech spać, we Włoszech gachować (NKPP II, p. 1010).

W Wegrzech się wino rodzi, a w Polsce umiera (NKPP II, p. 1010).

\section{The autostereotype of the Czech}

The main delineation of character is positive. In the proverbs a Czech is an honest, responsible person with a strong character:

Jakýs to Čech, že slovo nedržíšs (Bittnerová, Schindler 2002, p. 117; Čelakovský 1949, p. 553).

Čech dí, Čech splní (Bittnerová, Schindler 2002 p. 156; Čelakovský 1949, p. 416).

Pán Bůh Čecha neopustí, pakli sám sebe se nespustí (Bittnerová, Schindler 2002, p. 164).

Praví arciotec Čech: Co není tvého, toho nech (Bittnerová, Schindler 2002, p. 106; Čelakovský 1949, p. 177).

${ }^{1}$ Hereinafter, the Czech proverbs are from the defended in 2008 diploma work of the specialist, the graduate of Aleksandra V. Alekseeva, The ethnonyms in the Czech and English proverbs and idioms (the supervisor prof. Marina Yu. Kotova), that was kindly offered by the department of Slavonic Philology of St. Petersburg State University.
This is not only unshakable, but also an intelligent man:

Čech má hlavu svou, a to neustupnou (Bittnerová, Schindler 2002, p. 117; Čelakovský 1949, p. 553).

He aspires to the knowledge of the world:

Co Čech, to výzkumník (Bittnerová, Schindler 2002, p. 57).

In contrast to the autostereotype of the Pole the unity of the Czechs with another Slavic world is emphasized:

Čech všude bratra Slovana má (Bittnerová, Schindler 2002, p. 34).

\section{The stereotype of the Jew}

As the first group of heterostereotypes, we analyzed Polish and Czech proverbs that illustrate ideas of the Jews. For the analysis, proverbs which contain the component $\dot{Z} y d, \dot{Z} y d e k$, Žid were selected.

Jews are linked by a community of traditions and customs. These common cultural dominants allow us to consider them a closed group: language and culture tightly hold this society together, not allowing outsiders to invade their own isolated world.

If you compare the stereotype of a Jew with the stereotype of a Pole, you can see that the Jews do not treat the land where they live with love. In the proverbs, they do not farm the land, do not serve in the army, do not defend the country.

Nie orali Żydzi roli i orać nie będą (NKPP III, p. 983). Żyd nie orze i nie sieje, a młóci i wieje (NKPP III, p. 984)

It has historical reasons: the Jews were forbidden to buy land, so they had to look for other sources of income that were not related to agriculture.

However, the fact that Jews do not work on land and do not serve in the army does not exclude ways of finding earnings. There are a lot of words of the lexical-semantic field "trade" in the proverbs, which may indicate their occupation: buying and selling various things, goods, maintaining pubs, working at fairs, etc. Finances were always the main occupation of the Jews. First of all, in Poland, the Jews who arrived 
from the West were mainly engaged in trade, and then in loans and crafts (Żbikowski 2000, p. 26).

Bez jednego Żyda jarmark się nie obejdzie (NKPP III, p. 977).

Każdy Żyd swój towar chwali (NKPP III, p. 981).

Gdzie chłop traci, tam się Żyd bogaci (NKPP III, p. 980).

Mają pieniądze Żydzi, ale ich nikt nie widzi (NKPP III, p. 982).

Żyd nie szuka wosku, tylko zysku (NKPP III, p. 988).

The logical conclusion from such occupation will be the prosperous financial position of the person who does this: a correlation "a Jew is rich" appears.

Dlatego Żyd bogaty, że żyje z cudzej biedy i straty (NKPP III, p. 979).

These means are not most likely always earned honestly, as it is evidenced by the large number of proverbs that contain the words of the lexical-semantic field ,deception“:

Żyd dawno szalbierz (NKPP III, p. 988).

Jak nie ma w niebie dnia bez świętego, tak nie ma w święcie Żyda poczciwego (NKPP III, p. 980)

Żyd nie byłby Żydem, gdyby nie oszukał (NKPP III, p. 988).

Żydowska rzecz: obiecać, a nie dać (NKPP III, p. 990)

The lexeme ,cunning“ is also included in this field, and a sufficient amount of proverbs on this topic was found.

Myślał, że ujął Żyda za nogi, a on chwycił diabla za rogi (NKPP III, p. 982).

Jak sprzedać psa za lisa, żydowska jest sztuka (NKPP III, p.980).

Żyda tylko diabeł oszuka (NKPP III, p. 988).

Jak Żyd ciebie w oczy wychwala, uciekaj, bo to lala (NKPP III, p. 980).

Žid na šalbě neučil, ale s ní se narodil (Bittnerová, Schindler 2002, p. 164; Čelakovský, 1949, p. 572).

The annoyance of the Jew is also noted:

Jednymi drzwiami Żyda wypchnąć, to drugimi wlezie (NKPP III, p. 980). Mouchu, psa a žida když desetkrát odženeš, zase přijde (Čelakovský 1949, p. 572).

Lies, swindle determine the behavior of a Jew: according to the proverbs, they rob people, keep them in monetary bondage.

Gdzie chłop traci, tam się Żyd bogaci (NKPP III, p. 980).

Żyd czarcie nasienie, dybie na chłopa zniszczenie (NKPP III, p. 988).

Kto ze Żydem końca dojdzie, ten jak pies, co siedzi w budzie, głupi przyszedł, głupi pójdzie (NKPP III, p. 982).
Gdzie są Żydzi, tam człek grosza nie widzi (NKPP III, p. 980).

The Jews are also known as owners of pubs - this allows them to exploit the weaknesses of ordinary people. In the Polish proverbs the Poles have predilection for alcohol. The Jews, who are more restrained in the use of alcohol, use this bad habit to enrich themselves. They sell alcohol to the peasants on credit and encourage them in various ways to continue their feast and to spend more money.

Żyd gorzołke sprzedowo, ale ji nie pije (NKPP III, p. 988).

Kto na zastaw pije, tego Żyd obije (NKPP III, p. 981).

Nie znaj karczmy ni Żyda, nie dokuczy ci bieda (NKPP III, p. 983).

Another important feature of the stereotype of the Jews is greed.

Żyd rzadko w niełatanej sukni (NKPP III, p. 988).

Gdzie sa Żydki, tam i dydki (NKPP III, p. 980).

Wilk i Żyd nigdy nie syt (NKPP III, p. 985).

A person who earns money by money-lending can hardly be not greedy.

In this case certain behaviors are formed. One should avoid the help of the Jews, you cannot trust them, all contacts should be stopped - this is the basis of a quiet life.

Unikaj pomocy Żyda, głupiego rady, z sąsiadem zwady - a będziesz bezpieczny (NKPP III, p. 985).

Żydowi nigdy nie wierz (NKPP III, p. 988).

Na Żyda tak rachować można jak na zły zegarek (NKPP III, p. 982).

Nie znaj karczmy ni Żyda, nie dokuczy ci bieda (NKPP III, p. 983).

Nie zaczepiaj Żyda, bo będzie bieda (NKPP III, p. 983).

Piękniej z chłopami pracować, niż z Żydami szachrować (NKPP III, p. 983).

In the proverbs there is a comparison of the Jews with the animal. It is a wolf.

Wilk i Żyd nigdy nie syt (NKPP III, p. 985).

Wilka, Żyda i tłuka nikt poczciwy nie szuka (NKPP III, p. 985).

Żyd i wilk na próżno się nie krzątają (NKPP III, p. 988).

Żyd chrzczony, chłop nobilitowany, wilk chowany rzadko natury swojej zapamiętywają (NKPP III, p. 988)

Žid křtěný, vlk chovaný, mnich z kláštera vyhnaný - vše to stejné (Čelakovský 1949, p. 572).

Žid křtěný, vlk zkrocený, to je nepřitel smířený (Čelakovský 1949, p. 287) 
Symbolism allows to draw certain conclusions about the stereotype of a Jew. J. Bartmiński writes on the theme of the stereotype of a wolf in the Polish language picture of the world that a wolf is the embodiment of rapacity and savagery, it is dangerous for humans (Бартминьский 2005, p. 175). At the same time, it is an animal that is associated with a person: in fairy tales, the wolf is a dangerous companion and assistant to the main character; werewolves change their appearance on the appearance of this beast. A wolf is a creature that is alien to humans; it destroys livestock; it can harm people (Kapitsa 2009, p. 93). Therefore, a Jew, like a wolf, is dangerous to humans; his greed is comparable to the behavior of a predator.

The Jews practice a religion that is alien to the Czechs and Poles. This is also one of the causes of conflict between nations. The Jews are negatively regarded in terms of religious affiliation, compared with the devil.

Gdy diabeł nie może, Żyd mu dopomoże (NKPP III, p. 980).

Jak nie ma wody bez diabła, tak nie ma biedy bez Żyda (NKPP III, p. 980).

Żyd czarcie nasienie, dybie na chłopa zniszczenie (NKPP III, p. 980).

Żyd, Niemiec, diabeł trzeci jednej matki dzieci (NKPP III, p.988).

Żyda tylko diabeł oszuka (NKPP III, p. 989).

Gdzie Żyd łeb wsadzi, tam się diabeł wkinie (NKPP III, p. 980).

Křest'an skrze žida, jako čert srze babu (bývá ošizen) (Bittnerová, Schindler 2002,

p. 164; Čelakovský 1949, p. 572).

In Czech proverbs, there is a predominantly baptized Jew, but there is scornful attitude towards him.

Křest'an skrze žida, jako čert srze babu (bývá ošizen) (Bittnerová, Schindler 2002, p. 164; Čelakovský 1949, p. 572).

Se křtěným židem jen zas do vody (Čelakovský 1949, p. 572)

Žid křtěný, vlk chovaný, mnich z kláštera vyhnaný - vše to stejné (Čelakovský 1949 , p. 572).

Žid křrěný, vlk zkrocený, to je nepřitel smířený (Čelakovský 1949, p. 287).

\section{The stereotype of the German}

The Germans, despite of the neighbourhood to the Czechs and the Poles, have mostly negative characteristics in the proverbs. In the word "German" there is a reference to the fact that this person is "dumb", that is one who does not speak (meaning in Slavic languages), the one who became German; this sarcastic nickname was given the first Germans the Slavs met, and this name then spread to all that were close to him by language or appearance (Brückner 1970, p. 360).

Włożył język pod niecki, umie mówić po niemiecki (NKPP II, p. 605).

Mówi po niemecku, ale go Polak za kark bije (NKPP II, p.603).

Gdyby nie ten der-di-das, byłby ze mnie Niemiec (NKPP II, p. 603)

Mluvte s ním, když je Němec (Bittnerová, Schindler 2002, p. 61; Čelakovský 1949, p. 567).

The elementary differentiative feature of ethnic isolation of "the Germans" is the language used by Western neighbours: incomprehensible and difficult to understand, it always repelled the Poles (Rodziewicz 2009, p. 130).

Because of their belonging to another branch of the Christian religion, the Germans are considered foreigners, foes, and even heretics.

Nie każdego Niemca, który ma wąsy, się boją (NKPP II, p. 603).

Siedzi zając na przypiecku, mówi pacierz po niemiecku (NKPP II, p. 604).

Kto Niemcowi służy, temu diabeł płaci (NKPP II, p. 603).

Nie czyń grzechu nieczystego, strzeż się stroju niemieckiego (NKPP II, p. 603).

Niemiec w radzie, koza w sadzie, wilk w oborze, łgarz przy dworze, białogłowa na urzędzie - za diabła to wszystko bedzie (NKPP II, p. 604).

$\mathrm{S}$ ptákem dítě, kmet $\mathrm{s}$ mladicí, Němec $\mathrm{s}$ malvazím v láhvici, což nekřest'ansky zachází, když jim do rukou přichází (Čelakovský 1949, p. 567).

The mention of the devil can be often found in the proverbs. Like the Jews, the Germans are considered the creatures of the devil.

The Germans often have a negative intellectual characteristic in the proverbs.

Co się Niemiec rozumie na ogórku (NKPP II, p. 605).

Niemiec jak wierzba: gdzie go posadzisz, tam się przyjmie (tam rośnie) (NKPP II, p. 604).

Although their intellect is sometimes mentioned:

U Niemca ucz się rozumu, u Polaków cnoty (NKPP II, p. 605).

Their love for beautiful clothes and neat appearance is often shown in the proverbs. 
Zakochał się jak diabeł w niemieckim ubiorze (NKPP II, p. 605).

Śpieszy się jak Niemcy na jarmark (NKPP II, p. 605).

Nebojí se Němec, že mu gatě vezmou (Čelakovský 1949, p. 211).

A special feature of the Germans is greed.

U Niemców i mucha się nie pożywi (NKPP II, p. 605).

U Niemca co figiel, to grosz (NKPP II, p. 605).

Niemiecka oświata z kieszeni wymiata (NKPP II, p. 604).

Czego Niemiec za pieniądze nie zrobi? (NKPP II, p. 603).

Niemiec lepszy od Żyda, bo i wody na gorąco nie da się darmo napić (NKPP II, p. 604).

You can compare it with a Jew, in the stereotype of which this characteristic is also represented.

The Germans are also characterized as a sly nation.

Kde Němkyně, tam faleš; kde cikánka, tam krádež (Čelakovský 1949, p. 567).

Je Němec, nevěř (Bittnerová, Schindler, 2002, p. 117; Čelakovský 1949, p. 567)

They can swindle, you cannot trust them.

Perhaps because of the greed and stupidity of the Germans (as well as the lack of language contact), relations with them reached a deadlock, so it is difficult to do business with them, to negotiate something.

Pierwszej połkniesz promień słońca, nim z Niemcami dojdziesz końca. Zgoda z Niemcami jak wilkom z baranami (NKPP II, p.604).

Je Němec, nevěř (Bittnerová, Schindler, 2002, p. 117; Čelakovský 1949, p. 567).

In some contexts, the wolf appears, just as in the proverbs of the Jews.

Niemiec w radzie, koza w sadzie, wilk w oborze, łgarz przy dworze, białogłowa na urzędzie - za diabła to wszystko będzie (NKPP II, p. 604).

In general, the stereotype depicts a German in a negative light.

Niemiec dobry, ale trzy metry pod ziemia (NKPP II, p. 604).

Gdzie Niemiec staje, tam trawa nie rośnie (NKPP II, p. 603).

Nie każdego Niemca, który ma wąsy, się boją (NKPP II, p. 603).

Niemiec bez figla $z$ ławy nie spadnie (NKPP II, p. 603).

Lepší teplé pivo než studená Němka (Bittnerová, Schindler 2002, p. 126).

Dobrý Němec, mrtvý Němec (Bittnerová, Schindler 2002, p. 42).

Mol v drahém rúše, živá ryba na suše, vlk mezi kozami, žak mezi pannami, kozel v zahradě, Němec v české radě: kde to přebývá, tu dobře nebývá (Čelakovský 1949, p. 567).

The differences in culture, in religion, in many other spheres of life and proximity led to the fact that these nations are constantly compared and compared in the proverbs.
Póki świat światem, nie będzie Niemiec Polakowi bratem (NKPP II, p. 604). Niemcy pany, a Polany bydło (NKPP II, p. 603).

Polski most, niemecki post, włoskie nabożeństwo - wszystko to błazeństwo (NKPP II, p. 604).

Niemiec pyszny i hardy rad widzi krwawe boje, lecz pola nie dostoi, bo się Polaka boi (NKPP II, p. 604).

U Niemca ucz się rozumu, u Polaków cnoty (NKPP II, p. 605).

The Poles appear mostly in a winning position; they are not afraid of their neighbours, perhaps there is an excessive boast.

The Czech proverbs also show antipathies of the Czechs and Germans, these are completely different nations that will never have good relations.

Tenkrát Němec Čechu přeje, když se had na ledu hřeje (Bittnerová, Schindler 2002, p. 164; Čelakovský 1949, p. 567).

Němec bude tehdy Čechu přát, až se had na ledu bude hřát (Bittnerová, Schindler 2002, p. 164).

Spíše oráč dobrým knížetem bude, nežli Němec s Čechy věrně zbude (Bittnerová, Schindler 2002, p. 164).

Čech promokne na kůži, Němec durch um durch (Bittnerová, Schindler 2002, p. 97). My jsme my, a Němci jsú Němci (Bittnerová, Schindler 2002, p. 117).

\section{The stereotype of the Gypsy}

The proverbs have more archaic lexemes Cygan, cikán.

M. Zambrzycka says that in the Polish mentality the stereotype of a Gypsy is dual: on the one hand, it is treated as positive, according to which Gypsies are free people, sorcerers, musicians, in attractive colorful clothes with a lot of ornaments. The image of the Gypsy is romanticized. On the other hand, the Gypsies are homeless wanderers, lazy, robbers, crooks (Zambrzycka 2012, p. 2). If we appeal to the proverbial fund, we can distinguish the following features of the stereotype.

A lot of the proverbs contains the lexeme ,thief, deceiver, fraudster, theft". This is one of the main characteristics of the Gypsy.

Co Cygan, to szalbierz (NKPP I, p. 343).

Cygan w domu nie kradnie (NKPP I, p. 344).

Co Żyd naorze, to Cyganem lekko zawłóczy (NKPP I, p. 343).

Přivykl psotě jako cikán šibenici (Čelakovský 1949, p. 571). 
Besides a person who does not have a permanent place of residence, who will not work on the land or serve in the army. Horse trade and music playing are very popular (Bartosz 2008, p. 16). You can find proverbs that give an idea of the "fair" occupation of the Gypsies:

Co Cygan, to kowal (NKPP I, p. 343).

The "Gypsy-horses" correlation is one of the most common in this stereotype:

Cygańska kobyła trzy dni a dzień bieży (NKPP I, p. 344).

In the last proverb, there is no specific lexeme "horse", but the word kowal 'blacksmith' refers to one of the main occupations of a representative of this profession - shoeing horses. A person dealing with horses must be able to maintain them, including shoeing them.

You can correlate the main feature of the Gypsy 'thief, deceiver, crook' with the definition of 'cunning':

Cygan swymi dziećmi świadczy (NKPP I, p. 344).

Cygan za Cyganem, a ja za waspanem (NKPP I, p. 344).

A Gypsy is hiding behind other people, cheats, avoids unpleasant situations.

A Gypsy is undoubtedly a free man, he does not lead a sedentary lifestyle, he is constantly moving.

Niewolnik Cygan rzadko się nada (NKPP I, p. 345)

The Gypsies are also known for doing fortune telling, which is also reflected in the proverbs.

Každý cikán hádá podle své planety (Bittnerová, Schindler 2002, p. 35).

Zlý by z tebe byl cikán, neumíš hádati (Čelakovský 1949, p. 571).

Another features of a Gypsy are his cheerfulness, craving for music, entertainment and festivals. Wedding is one of these events.

Bez Cygana wesele się nie obejdzie (NKPP I, p. 343).

Cygan się pyszni, kiedy czerwone spodnie nadzieje (NKPP I, p. 343).

Cygan bez drumli jako dziad bez jeża (NKPP I, p. 343).

A bear as an animal attribute of a Gypsy is also represented in the proverbs.

Niedźwiedź tańcuje, a Cygan pieniądze bierze (NKPP I, p. 345).
The mention of the dark complexion of the Gypsy is in the proverbs of both nations.

Szkoda myć Cygana i tak czorny zostanie (NKPP I, p. 345).

Cikána mýti márná práce (Bittnerová, Schindler 2002, p. 79; Čelakovský 1949, p. 482).

\section{The stereotype of the Turk}

In the proverbial picture of the world of the Poles and the Czechs, the Turks are cowardly, weak and stupid people:

Bije się jak Turek, chowa się za murek (NKPP III, p. 548). Černý jak Turek a hlupý jak lulek (Zaorálek 1963, p. 602).

Poturčenec horší Turka (Bittnerová, Schindler, 2002, p. 29).

Their dark complexion is also mentioned. Their faith is also wrong (as many other nations with other religions, such as the Germans and Jews).

Nad Turki i Tatary nie ma gorszej wiary (NKPP III, p. 548).

In general, the stereotype of a Turk is negative in both languages.

\section{The stereotype of the Hungarian}

The stereotype of the Hungarians is ambiguous. In all the Polish proverbs there is a friendly attitude towards the representatives of this nation, the most famous proverb to present day is:

Polak, Węgier dwa bratanki i do szabli i do szklanki (NKPP III, p. 675).

There is also a common weakness of both nations for alcohol:

W Węgrzech się wino rodzi, a w Polsce umiera (NKPP III, p. 675).

W Polszcze jeść, w Węgrzech pić, w Niemczech spać, we Włoszech gachować (NKPP III, p. 675).

The Hungarians in proverbs are sister nation that has a positive characteristic. In the Polish picture of the world, they are just like the Poles, associated with alcohol.

Unlike the Polish the Czech proverbs demonstrate a negative attitude towards the Hungarians.

Uhru žádnému nevěr̆, leč který má tři oči v čele (Čelakovský 1949, p. 576). Dá až na uherský měsíc (Čelakovský 1949, p. 576). 
The last proverb has the meaning 'after a very long time, never'. Therefore, we can conclude that in the Czech proverbial picture of the world the Hungarians are unreliable, guileful people.

\section{Conclusions}

The analysis of the proverbs let us reveal the distinctive features of ethnic stereotypes in the Czech and Polish proverbs.

The idea of themselves in the Polish language picture of the world is rather positive. In the proverbs the important qualities of the Poles are their nobility, patriotism, religiosity. The opposite characteristics will be weakness for alcoholic beverages and abundant nourishing food, as well as untidiness, rudeness, ignorance. In general, there are more proverbs with positive connotation than with negative connotations.

The autostereotype of the Czechs is positive. Representatives of this nation are distinguished by their mental abilities, honesty, decency, strong character.

A Jew in the Polish proverbs is not engaged in the work that resides in the Poles: he does not plow, he does not serve in the army. The means for living for a Jew are the maintenance of taverns and operations with money; these occupations bring him good profit, which allows him to live comfortably and increase his fortune. A Jew often reaches prosperity in dishonest way, since he is cunning.

In the proverbs a German is a stranger, speaks an incomprehensible language and adheres to the wrong religion. He does not deserve confidence and respect. The stereotype dualism is expressed in the positive interpretation of the mental abilities of the Germans. In the stereotype of the German there are definitions of 'devil', 'wolf', 'greed'

In the stereotype of a Gypsy we identified the following characteristics. First of all, a Gypsy is a thief, a deceiver and a cunning one, and secondly, he is a nomad, a tramp, does not live in one place, constantly moves. A Gypsy loves fun, music, festivals and he also has dark complexion.
In the characteristics of the Turks a main role is played by their different (in relation to the Poles) religion. They are also cowardly, stupid, and made a negative impression.

In the proverbs the Hungarians are a sister nation for the Poles, but alien and antipathetic for the Czechs.

\section{Source shortcuts}

NKPP I Nowa księga przystów i wyrażeń przystowiowych polskich, red. J. Krzyżanowski, t. I. Warszawa: Panstwowy Instytut Wydawniczy, 1978.

NKPP II Nowa ksiega przystów i wyrażeń przyslowiowych polskich, red. J. Krzyżanowski, t. II. Warszawa: Państwowy Instytut Wydawniczy, 1978.

NKPP III Nowa ksiega przystów i wyrażeń przystowiowych polskich, red. J. Krzyżanowski, t. III. Warszawa: Państwowy Instytut Wydawniczy, 1978.

\section{Bibliography}

B a r t o s z A., 2008, Poznajemy historię Romów, Szczecinek: Związek Romów Polskich: Instytut Pamięci i Dziedzictwa Romów oraz Ofiar Holokaustu.

B it t n e rová D., S c h indle r F., 2002, Česká př́sloví: Soudobý stav konce 20. století, Praha: Univerzita Karlova v Praze.

B r ü c k n e r A., 1970, Stownik etymologiczny języka polskiego, Warszawa: Wiedza Powszechna

Č e la k ov s ký F. L., 1949, Mudroslovi národu slovanského ve přislovích: Připojena jest sbirka prostonárodnich českých pořekadel, Praha: Vyšehrad.

$\mathrm{K}$ a $\mathrm{p}$ it s a F.S., 2009 Slavianskie traditsionnye verovaniia, prazdniki i ritualy: spravochnik [Slavic tradition beliefs, holidays and rituals: handbook], Moscow, Flinta Nauka.

R o d z i e w i c z B., 2009, Póki świat światem, nie będzie Niemiec Polakowi bratem - językowy stereotyp Niemca (model archaiczny). „Annales Neophilologiarum" [Szczecin], nr 3, s. 129-135.

Slovník české frazeologie a idiomatiky, 2009, red. Fr. Čermák [et al.], Praha: LEDA.

Z a mbrzycka M., 2012, Stereotypowe wizerunki Cyganów-Romów w kulturze i języku polskim, [w:] Kultura i Historia, t. 22, Lublin. Online: http://www. kulturaihistoria.umcs.lublin.pl/archives/4211 [accessed 28 March 2016]

Z a o r á 1 e k J., 1963, Lidová rčení. Praha: Nakladatelství Československé akademie věd.

Ż b i k ow s ki A., 2000, Żydzi. Wrocław: Wydawnictwo dolnośląskie.

Б а р т м и н ь с к и й Е., 2005, Языковой образ мира: очерки по этнолингвистике, Москва: Индрик. 